\title{
FORMATION OF COMPETITIVE ADVANTAGES OF ENTERPRISES IN TERMS OF GLOBALIZATION: COMPETITIVE DYNAMICS AND AN INTELLECTUAL COMPONENT
}

\author{
Oleg Tarasenko', Yurii Yermakov² \\ National Academy of Internal Affairs of Ukraine, Ukraine \\ Vitalii Pchelin ${ }^{3}$ \\ Kharkiv National University of Internal Affairs, Ukraine
}

\begin{abstract}
The purpose of the article is to investigate the current state of scientific thought in relation to the formation of intellectual capital of an enterprise in the innovation process, achievement by the enterprise of corresponding competitive advantages and their protection. Methodology. The methodological basis of the article is the systematic approach, which provided a comprehensive definition of the scope of this research intellectual property and its protection as a complex economic and legal category. This made it possible to systematically define the purpose, level of abstraction, hierarchy, forms of manifestation, and key attributes of the subject of research. Application of principles of modelling of business processes also allowed studying the influence of factors of the external environment on the sequence of information flows in the process of forming competitive advantages on the basis of intellectual property. In addition, having determined the scientific basis, the collective and local monographic studies of leading scientists concerning the specificity of the formation of competitive advantages of innovative enterprises, including on the basis of intellectual capital, were also taken into account. Results. The article studies, describes and, correspondingly, formalizes modern processes of formation of competitive advantages in the conditions of Smart Economy: knowledge management, their patenting, modern significance, and the influence of patenting on the role of intellectual property in the investigated phenomena, as well as management of relevant information flows. Practical implications. The research demonstrates ways of forming competitive advantages in the modern economy, and the results of the analysis of relevant statistics explain patterns of economic and legal processes in the field of relevant practical activities. This allows assessing the actual state of the subject of the research, determining the development trajectory, and effectively forming methods and tools for managing the relevant processes. Value/originality. The proposed approach allows ensuring the principle of unity in the research of economic and legal processes in the field of innovation activity management. The work simultaneously synthesizes important aspects of information flow management, intellectual capital formation, and intellectual property protection in the process of commercialization of results of innovation activities.
\end{abstract}

Key words: globalization, intellectual economy, competitive advantage, competitiveness, intellectual property, patent.

JEL Classification: K22, D29, F23

\section{Introduction}

The process of globalization of the world economy is characterized by rapid qualitative and quantitative changes; modern economic relations are regulated by a large number of economic and legal regulators, and especially in this progressive part as an innovative direction. The activity in the innovation sphere provides the enterprise with the most influential and stable competitive advantages. Therefore, from the scientific point of view, the study of regularities and peculiarities of the processes of formation of intellectual capital of an enterprise in the innovation process as a basis for the formation of the competitiveness of a modern enterprise is important today.

\footnotetext{
Corresponding author:

${ }^{1}$ Department of Operative and Searching Activity, National Academy of Internal Affairs of Ukraine.

${ }^{2}$ Department of Criminal Procedure, National Academy of Internal Affairs of Ukraine.

${ }^{3}$ Department of Administrative Law and Procedure, Kharkiv National University of Internal Affairs.
} 


\section{Formation of modern competitive advantages of enterprises in terms of globalization}

The globalization of the economy ensures cooperation in the production of fundamentally new products, creativity and use of the latest technologies due to access to new external ideas while respecting the protection of intellectual property (IP). As V.F. Maksimova correctly notes, the accompanying process of globalization of the economy today is the formation of a new stage in the development of economic relations - Smart (intellectual) economy. The need for the transition to Smart economy is caused by the underlying causes that determined the vector of the transformation of all spheres of society by increasing the efficiency of economic resources through innovation, intellectualization, institutionalization, environmentalization, and socialization (Maksimova, 2011).

It should be noted that the positivity of these tendencies not abolishes but, on the contrary, increases the intensity of economic competition since as S.V. Kondratjukov and S.S. Staurskij correctly specify, reasons for the emergence of competition objectively laid down by the living nature, dictated by the condition of survival, when coming-into-being as a result of bioevolution of two or more organisms of the same type with the general goals of existence and a single habitat immediately required competition for limited resources (Kondratjukov, 2015).

Taking into account such properties of the modern development of globalization of economic processes, in our opinion, the successful definition of the essence of competitiveness is proposed by M.V. Bondarenko and L.O. Ihnatenko, they understand competitiveness as a property of an object having a certain share of the corresponding relevant market, which characterizes the degree of conformity of the technical-functional, economic, organizational, and other characteristics of the object with the requirements of consumers, determines the market share belonging to this object, and prevents redistribution of this market in favour of other objects (Bondarenko, 2007).

Yu.O. Zaitsev, having comprehensively explored the versatile contemporary scientific views on the essence and characteristics of competitiveness and evaluating it as an element of the system of economic competitive relations, identified the following properties of competitive advantage:

1) competitive advantage is an element in the system of competitive relations;

2) competitive advantage manifests itself in conditions of competition;

3) competitive advantage is relative;

4) competitive advantage has a dynamic nature, and a steady competitive advantage - a long-term benefit from the application of some unique, based on a unique combination of intra-firm resources and the state of the environment, which, due to uniqueness, cannot be copied (Zaitsev, 2015).

It should be specified that the most stable competitive advantage in the Smart economy is provided by the intellectual component, including IP.

Several IP roles that it can perform in the process of forming competitive advantages are proposed by A.M. Prohorov: in the first place, it affects the formation of the resource potential of the enterprise (is a part of the organization's material, commercial, informational, and financial potential); is a kind of "foundation" of the innovative potential of the organization, which composition and structure determine its innovative capabilities, and hence directions of development of the competitive potential of the organization as a whole; it is also an economic tool that ensures the transformation of existing competitive capabilities of the organization into the corresponding competitive advantages, besides, it remains the source of additional competitive advantages of the organization (Prohorov, 2013).

At the same time, it should be noted that even being involved with globalization, institutionalized national differences in knowledge management remain in the economies of different leading countries. Thus, the intellectualization of the innovative potential of a modern economic organization can take place in various ways, including under the influence of features of the national peculiarity of enterprise management, an example of which is given in Table 1 (Belova, 2016).

However, through the prism of formation of competitive advantages and their protection,

Table 1

Comparison of knowledge management approaches

\begin{tabular}{|l|l|l|}
\hline \multicolumn{1}{|c|}{ Direction } & \multicolumn{1}{|c|}{ The main ideas } & \multicolumn{1}{c|}{ The result of the activity } \\
\hline American approach & $\begin{array}{l}\text { Use of shared knowledge of employees, rather than } \\
\text { individual aspects. }\end{array}$ & $\begin{array}{l}\text { Organization of communities, in which people share } \\
\text { information and knowledge that exist both in physical } \\
\text { and virtual space. }\end{array}$ \\
\hline Japanese approach & $\begin{array}{l}\text { Socialization. Change in the organizational } \\
\text { environment. Search for alternative approaches to } \\
\text { solving problems. }\end{array}$ & $\begin{array}{l}\text { The company creates new knowledge and information } \\
\text { necessary for a new approach to the problem and its } \\
\text { solution. }\end{array}$ \\
\hline $\begin{array}{l}\text { Scandinavian (European) } \\
\text { approach }\end{array}$ & $\begin{array}{l}\text { Intellectual capital is the result of independent actions } \\
\text { of individuals. }\end{array}$ & $\begin{array}{l}\text { Promotion of new ideas within the company due to } \\
\text { independent opinions of individual employees. }\end{array}$ \\
\hline
\end{tabular}

Source: (Belova, 2016) 
the simultaneous internationalization and institutionalization of economic and legal processes, including the protection of intellectual rights both at the stage of patenting and the control of the protection of rights in the process of exchange, are the important advantage of globalization.

\section{Protection of intellectual property in the innovation process}

Recently, great importance in increasing the competitiveness of goods, as noted by O.V. Kirillov, is assigned to brand names, service marks, and trademarks. The competitiveness of commodity producers is largely manifested through the competitiveness of their products, which, in turn, is influenced by:

- availability of patent or non-patent protection;

- patent cleanliness of the equipment object;

- the name of the place of origin of goods, service marks and registered trademarks;

- applied technology;

- a number of patents, licenses available in the organization.

A significant factor affecting the competitiveness of the product is its patent clearance. At the same time, patent clearance is understood as the legal property of an object, the essence of which is that it does not violate the exclusive rights of IP (including industrial) in the given country, owned by third parties, and can be freely implemented in this country (Kirillov, 2014). But over time, patent clearance may also appear in relation to other countries since other patents may expire in connection with, for example, expiry, etc.

In this perspective, it is advisable to pay attention to the point of view of the S.P. Rogozhin and S.L. Sazanova, who noted that in the era of globalization of the economy, the active influence and interaction of legal and economic theories on the institute of IP, there is a need for its study as an economic and legal category, and the concept of "intellectual property right" should be considered as an institutionalization process for the protection of competitive advantages of the enterprise, which creates incentives and rules of economic behaviour (Rogozhin, 2016).

Investigating the protection of IP rights in today's globalization, one should pay attention to D.M. Chybisov's research, which states that the emergence of IP protection was associated with the possibility of commercialization of IP results. The current concept of the protection of industrial property is provided for, in particular, in the Agreement on Trade Aspects of IP Rights, also provides patent protection of the invention only on condition that it is commercially viable (Article 27 of the Agreement), which may indicate that it is precisely industrial suitability of the result of a certain intellectual activity plays key role in the property protection of IP (Chybisov, 2017).

Assessing the impact of patent clearance on the product competitiveness, it is possible to indicate respectively the economic and legal component of influence:

1) losses from potential claims of the patent holder, as sanctions for patent infringement must be substantial, which ensures the effectiveness of IP protection;

2) the legal component requires compliance with the rules and defined actions in the set of legal relations, including the determination of the extent of rights of existing patents and possible objections associated with the patent in a particular country at a particular time, such as, for example, in relation to expiration or for other reasons, patents whose validity may have expired earlier.

An assessment of the importance of using patent information in the innovation process, which was obtained by experts from the European Patent Office (EPO) as a result of the study (EPO, 2017), is presented in Fig. 1.

According to EPO data, approximately $80-90 \%$ of respondents who innovate believe that technical information is significant at all stages of the innovation process. Information about business processes and property rights protection is of particular importance at the stages of applied research and subsequent commercialization; in general, the assessment of the importance of these types of information at all stages of the innovation process is approximately equal and makes up $65 \%$ of positive responses.

The source of technical information for the innovation process is, above all, Internet resources that are useful to more than $80 \%$ of inventors. The next important is the technical information that can be obtained from patent sources (more than $70 \%$ ), followed by printed media (over $60 \%$ ), personal contacts, databases, exhibitions and conferences, professional associations, forums, blogs, etc.

In general, information from patent sources is used at the stage of theoretical studies in $37 \%$ of cases, in the applied research stage $-76 \%$, at the stage of design work $-77 \%$, and at the stage of commercial

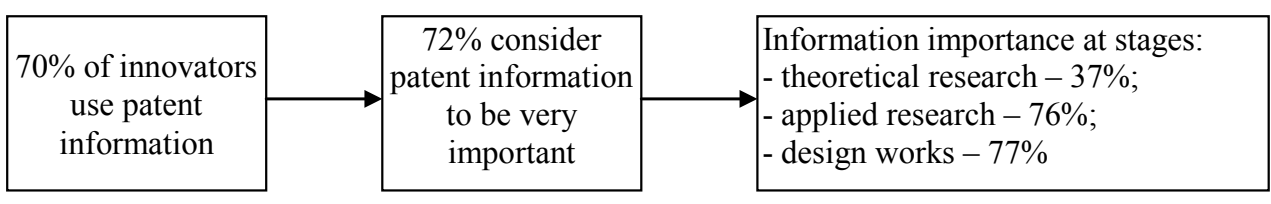

Fig. 1. The importance of using patent information in the innovation process

Source: compiled by the author on the basis of annual reports from the European Patent Office 
implementation - in $67 \%$ of cases. Patent information resources are mainly the European Patent Office (75\%), the German Patent and Trademark Office (DPMA) (30\%), the United States Patent and Trademark Office (USPTO) (21\%), the World Intellectual Property Organization (WIPO) (17\%), Google (15\%), and others. The importance of using patent information at the stages of the innovation process is noted by more than half of the respondents.

At the same time, obstacles to the use of patent information are the following factors: patent information has lost its relevance to innovators; unknown sources for obtaining patent information; patent information is too complicated, obsolete or expensive.

At the same time, in practice of the majority of firms in developed countries of the world, the study of patent clearance represents at least half of all types of patent research and is an important part of the commercial activity in the creation and sale of products, technologies, and services. Work on the provision and research of patent clearance is carried out before the beginning of the object's implementation, that is, during its development. Participants in this process are both developers and specialists in the field of IP: patent workers, lawyers, economists (Kirillov, 2014).

\section{Information component of the competitiveness management process}

Another important factor contributing to the growth of competitiveness in the context of globalization is the dynamic capacity for the synergy of information, production, financial, and other resources in order to obtain maximum effect.

The information component in such a combination plays a key role since it connects all kinds of resources to a single decision-making system. The interconnection of elements of the decision-making system with the dominant role of information enables the organization to create new ones and to improve the existing strategies of competitiveness. In other words, the information component of the competitiveness management process is, in our opinion, one of the key factors for success.

It follows that the task of managing the competitiveness of enterprises in the current dynamic conditions pushes the enterprise to construct such business processes, the dominant characteristic of which should be both intellectualization of global marketing information flows and the ability of an innovative product of enterprise to best meet the needs of specific consumers, while providing competitive activity with simultaneous protection of the sources of its Smart competitive advantage. Consequently, in our opinion, the intellectualization of competitive market advantages is ensured, on the one hand, by the permanent updating of competitive knowledge on the basis of effective organization of the marketing information system and, on the other hand, by the ability of the enterprise to protect its intellectual capital.

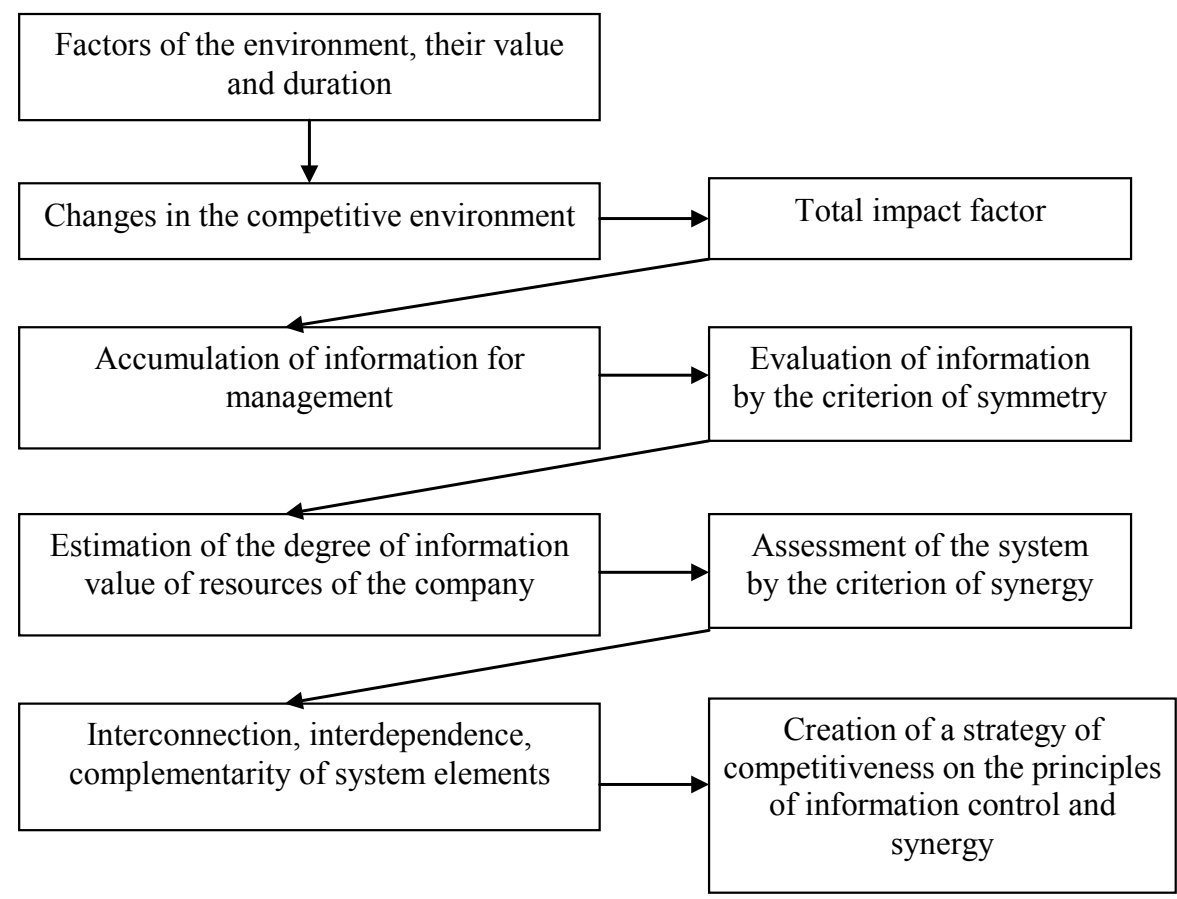

Fig. 2. Influence of environmental factors on the formation of competitiveness strategies Source: developed by the author 
The development of competitiveness as a process can be represented by modelling the influence of environmental factors on information flows in the process of formation of competitiveness strategies, as shown in Fig. 2.

The resulting impact factor for the company, which causes changes in the competitive position, is the difference between the increase and decrease in the volume of information the specific fluctuation that an organization achieves due to exchange with the external environment. Increasing the volume of information exchange leads to the effect of scale but complicates the process of its ordering.

Data collection and analysis requires consideration of the factor of symmetry of information, which shows the degree of ownership of information of various subjects of market relations. The unevenness of information flows causes the inappropriate behaviour of market participants, may lead to additional losses and, as a consequence, a possible restriction of competitive positions. In this case, it is advisable to use mechanisms for optimizing information flows.

\section{Conclusions}

According to the research results, the following conclusions can be made: one of the prerequisites for the successful functioning of the mechanism of formation of intellectual capital of the enterprise is the verified management of the organization's information and scientifically substantiated provision of the process of obtaining the necessary information with the expected effects of their implementation; the formation of sustainable competitive advantages today should be ensured on the basis of intellectual capital in the process of innovation activity; the preservation of such competitive advantages of enterprises, including through patenting, is gaining increasing importance in the context of globalization, which is conditioned by the need for further research in this direction.

\section{References:}

Maksimova, V. F. (2011). Smart (intellektualnaja) jekonomika: celi, zadachi i perspektivy. Otkrytoe obrazovanie, 3: 63-71.

Kondratjukov, S. V., Staurskij, S. S (2015). Prichiny, uslovija i posledstvija konkurencii. Omskij nauchnyj vestnik, 4 (141): 256-259.

Bondarenko, M. V., Ihnatenko, L. O. (2007). Rozrobka ta obgruntuvannya systemy orhanizatsiynoho ta informatsiynoho zabezpechennya upravlinnya mizhnarodnoyu konkurentospromozhnistyu pidpryyemstva. Kommunalnoe khozyaystvo horodov, 78: 11-31.

Zaitsev, Yu. O. (2015). Teoretichni osnovi formuvannja konkurentnih perevag agrarnih pidpriєmstv. Visnyk KhNAU im. V.V. Dokuchayeva. Seriya „Ekonomichni nauky”, 5: 68-82.

Prohorov, A. N. (2013). Rol intellektualnoj sobstvennosti v povyshenii urovnja konkurentosposobnosti organizacii. Vektor nauki TGU, 4: 141-144.

Belova, E. O. (2016). Intellektualnyj kapital kak strategicheskij faktor razvitija organizacij. Nauchno-metodicheskij jelektronnyj zhurnal «Koncept», [Electronic resource]. - Mode of access: http: //e-koncept.ru/2016/76068.html Kirillov, A. V. (2014). Razvitie konkurentnyh preimushhestv predprijatija na osnove kommercializacii obektov intellektualnoj sobstvennosti. Vestnik Universiteta, [Electronic resource]. Retrieved from: https://cyberleninka.ru/ article/n/razvitie-konkurentnyh-preimuschestv-predpriyatiya-na-osnove-kommertsializatsii-obektovintellektualnoy-sobstvennosti

Rogozhin, S. P., Sazanova, S. L. (2016). Intellektualnye prava sobstvennosti: institucionalnyj podhod. Upravlenie, 1(11): 74-78.

Chybisov, D. M. (2017). Okhorona prav intelektualnoyi vlasnosti v ramkakh Svitovoyi orhanizatsiyi torhivli. Odesa. Odeska yurydychna akademiya: 272.

The role of patent information in innovation management. Results of a survey by the EPO [Electronic resource]. Retrieved from: http://documents.epo.org/projects/babylon/eponot. nsf/0/35D952CFB1E36E9CC12581CB004EC72D/\$File/0811_11.00_h_wongel_-_the_role_of_pi_in_ innovation_en.pdf 